\title{
PERANAN KOMITE AUDIT DAN DEWAN PENGAWAS SYARIAH TERHADAP KUALITAS LAPORAN KEUANGAN (Studi Kasus pada BPRS di Jawa Timur)
}

\author{
Iin Fitri Lestari ${ }^{1}$, Ulfi Kartika Oktaviana² \\ 1,2 Fakultas Ekonomi Universitas Islam Negeri Maulana Malik Ibrahim Malang \\ Indonesia
}

$\bowtie$ Corresponding Author:

Nama Penulis: Iin Fitri Lestari

E-mail: iinfitrilestari04@gmail.com

\begin{abstract}
Audit Committee and Sharia Supervisory Board are the parts of the organization which help to manage the financial reports of BPRS with high quality. The aim of this research is to find out the influences of the Audit Committee's and Sharia Supervisory Board's role toward the quality of financial reports especially in BPRS of east java. This study applies a quantitative approach, focused on associative type. Moreover, the sample is taken by using purposive sampling method. The objects are 15 institutions of BPRS in east java which are registered in OJK and BI, each BPRS is given a questionnaire and it was returned around 38 questionnaires. After the data was collected, it was directly processed and analyzed by using statistical application that is SPSS 16. The variable of the research involves 7 indicators of Audit Committee responsibilities, 9 indicators of DPS supervision activities, and 9 indicators of financial report quality. Consequently, the research result provides that according to a partial test, there is a good effect between the roles of the audit committee towards the quality of financial reports. Based on a partial test, there is a bad effect between DPSs' roles towards the quality of financial reports. According to the simultaneous test, Audit Committee together with DPS influence the quality of financial reports.
\end{abstract}

Key Words: Audit Committee, DPS, Quality of Financial Reports, BPRS.

\section{Abstrak}

Komite Audit dan Dewan Pengawas Syariah adalah pihak-pihak dalam organisasi yang membantu penyusunan laporan keuangan yang berkualitas pada BPRS. Tujuan dari penelitian ini adalah untuk mengetahui seberapa besar pengaruh peranan Komite Audit dan Dewan Pengawas Syariah terhadap Kualitas Laporan Keuangan di Bank Pembiayaan Rakyat Syariah (BPRS) Provinsi Jawa Timur. Penelitaian ini menggunakan pendekatan kuantitatif bersifat asosiatif. Sampel diambil dengan metode purposive sampling. Objek penelitian ini sebanyak 15 BPRS di Jawa Timur yang terdaftar dalam OJK dan BI, dengan masing-masing BPRS disebarkan kuisioner dengan total kuisioner yang dikembalikan sebanyak 38. Variabel penelitian meliputi 7 indikator tanggungjawab Komite Audit, 19 indikator aktivitas pengawasan DPS, dan 9 indikator kualitas laporan keuangan. Dari 
hasil penelitian ini menunjukkan bahwa menurut uji parsial, terdapat pengaruh positif antara peranan komite audit terhadap kualitas laporan keuangan. Peranan DPS berpengaruh negatif terhadap kualitas laporan keuangan. Menurut uji simultan, Komite Audit dan DPS secara bersamasama berpengaruh terhadap kualitas laporan keuangan.

Kata Kunci : Komite Audit, DPS, Kualitas Laporan Keuangan, BPRS.

\section{PENDAHULUAN}

Laporan keuangan adalah sumber informasi yang dipercaya para pemakai laporan keuangan untuk mengetahui kinerja manajemen dan posisi keuangan perusahaan. Laporan keuangan pada bank syariah mempunyai peranan yang penting untuk memberikan bagi hasil yang tepat pada nasabah pendanaan dan menerima bagi hasil dari nasabah pembiayaan. Laporan ini juga harus didukung oleh pengendalian intern atas pelaporan keuangan yang berkualitas (Vivin \& Wahono, n.d.). Laporan keuangan yang berkualitas harus sesuai dengan prinsip akuntansi yang berlaku umum dan memenuhi aturan yang ada (Rini, 2014).

Laporan keuangan yang berkualitas tidak dapat dihasilkan oleh penyusun laporan keuangan saja, tetapi penyusun laporan keuangan harus bekerja sama dengan pihak lain dalam organisasi yang dapat membantu dalam menjaga kualitas laporan keuangan (Rini, 2014). Pihak- pihak lain dalam organisasi tersebut diantaranya adalah Komite Audit dan Dewan Pengawas Syariah (DPS) (Sholikah et al., n.d.).

Komite audit merupakan salah satu perangkat Dewan Komisaris Bank yang dibentuk berdasarkan keputusan Dewan Komisaris yang bekerja secara kolektif dan berfungsi membantu serta bertanggung jawab kepada Dewan Komisaris (Piagam Pedoman Kerja Komite Audit, 2017). Efektifitas komite audit dalam memantau proses pelaporan keuangan memiliki keterkaitan antara karakteristik komite audit dengan kualitas laporan keuangan. Untuk memastikan laporan keuangan yang berkualitas, diperlukan Komite Audit yang berkompeten dalam menjalankan fungsi dan tanggungjawabnya.

Komite Audit dalam menghasilkan laporan keuangan yang berkualitas, juga dibantu oleh DPS. DPS dibentuk dengan tujuan untuk memastikan oprasional Bank Syariah telah sesuai dengan peraturan syariah (Riduwan et al., 2018). Pelanggaran pada ketentuan ini diancam dengan sanksi administratif, mulai dari bentuk denda uang hingga pada pencabutan izin usaha bank. DPS merupakan badan independen yang ditempatkan pada suatu bank syariah yang berperan mengawasi penerapan prinsip syariah dalam kegiatan usaha bank (Faozan, 2013).

DPS adalah suatu badan yang diberi wewenang untuk melakukan supervisi/ pengawasan dan melihat secara dekat aktivitas lembaga keuangan 
syariah agar senantiasa mengikuti aturan dan prinsip syariah (Suazhari, 2015). Peran DPS merupakan salah satu point yang sangat penting bagi terjadinya praktik Bank Syariah. Bila DPS benar-benar menjalankan wewenang dan kewajibannya (peran) bisa dipastikan bahwa laporan keuangan yang terjadi adalah laporaran keaungan yang berkualitas dan sesuai dengan prinsip syariah (Suazhari, 2015).

Bank Pembiayaan Rakyat Syariah atau sering disebut BPRS adalah salah satu lembaga keuangan perbankan syariah, yang pola operasionalnya mengikuti prinsip-prinsip syariah ataupun muamalah islam. Keberadaan BPRS sangat membantu UMKM dalam hal peminjam modal karena prosedur peminjaman yang mudah dibandingkan Dengan Bank Syariah lainnya.

Penelitian ini dilakukan di BPRS karena salah satu variable independen yang digunakan adalah peran dari Dewam Pengawas Syariah (DPS). Sedangkan DPS itu sendiri tidak terdapat pada BPR ataupun Bank Konvensional lainnya. DPS merupakan salah satu organ penting dalam BPRS. Selain itu, jumlah BPRS di provinsi Jawa Timur, berada pada urutan pertama, yakni berjumlah 29 BPRS.

\section{KAJIAN PUSTAKA}

Bank Pembiayaan Rakyat Syariah (BPRS) adalah lembaga keuangan Bank yang dibawahi oleh dewan kebijakan moneter, yang melakukan kegiatan ekonominya berdasarkan prinsip Islam atau syariah, tanpa menghalalkan adanya riba atau suku bunga yang berorientasi pada masyarakat di tingkat desa ataupun kecamatan. Untuk menghasilkan laporan keuangan yang berkualitas dalam BPRS, pembuat laporan keuangan dibantu oleh Komite Audit dan Dewan Pengawas Syaria (DPS).

Komite Audit adalah suatu kelompok yang sifatnya independen atau tidak memiliki kepentingan terhadap manajemen dan diangkat secara khusus serta memiliki pendangan antara lain bidang akuntansi dan hal-hal lain yang terkait dengan sistem pengawasan internal perusahaan (Swingly \& Sukartha, 2015).

Dewan Pengawas Syariah adalah dewan yang bertugas memberikan nasihat dan saran kepada Direksi serta mengawasi kegiatan Bank agar sesuai dengan Prinsip Syariah. Dalam Surat Keputusan Direksi Bank Indonesia ayat 2 dan 3 pasal 19 tanggal 12 Mei 1999, cukup jelas disebutkan bahwa: Bank wajib memiliki Dewan Pengawas Syariah yang berkedudukan di kantor pusat bank (Head Office). Persyaratan sebagai anggota Dewan Pengawas Syariah diatur dan ditetapkan oleh Dewan Syariah Nasional. DPS merupakan salah satu pembeda antara Bank Islam dan Bank Konvensional, dimana fungsi utamanya adalah mengawasi kegiatan operasional telah memenuhi shariah 
compliance (kesesuaian dengan aturan syariah) sebagai justifikasi penting dalam perbankan dan keuangan syariah.

Kualitas laporan keuangan dapat dikatakan baik apabila informasi yang disajikan dalam laporan keuangan tersebut dapat dipahami, dan memenuhi kebutuhan pemakainya dalam pengambilan keputusan, bebas dari pengertian yang menyesatkan, kesalahan matrial serta dapat diandlkan, sehingga laporan keuangan tersebut dapat dibandingkan dengan laporan keuangan periode-periode sebelumnya (Adhi \& Suhardjo, 2013). Namun demikian, perlu disadari bahwa laporan keuangan tidak menyediakan semua informasi yang mungkin dibutuhkan pengguna dalam pengambilan keputusan ekonomi. Secara umum, laporan menggambarkan pengaruh dari kejadian masa lalu, dan tidak diwajibkan untuk menyediakan informasi non keuangan (Yosefrinaldi, 2013). Dalam SAK 1, karekteristik kualitas laporan keuangan yang harus dipenuhi adalah: Relevan, Andal, Dapat Dibandingkan dan Dapat Dipahami.

\section{HIPOTESIS}

Komite Audit adalah komite yang membantu pelaksanaan tugas dan tanggungjawab Dewan Komisaris terkait dengan audit intern dan ekstern. Untuk itu, fungsi audit laporan keuangan menjadi wewenang Komite Audit. Sebagai penangungjawab atas audit laporan keuangan maka Anggota Komite Audit harus independen, objektif dan profesional dalam mengaudit laporan yang telah dibuat sebagai dasar dalam pengambilan keputusan. Berdasarkan argumen diatas maka peneliti menduga peran Komite Audit mempuyai pengaruh terhadap kualitas laporan keuangan karena citra dan kredibilitas Bank Syariah di mata stakeholder akan bergantung pada opini yang diberikan oleh Komite Audit. Hal ini sesuai dengan penelitian yang dilakukan oleh Rini (2014) tentang Pengaruh Penerapan Peran Komite Audit, Peran Dewan Pengawas Syariah, dan Efektivitas Pengendalian Intern Atas Pelaporan Keuangan Terhadap Kualitas Pelaporan Keuangan. Hasil penelitian tersebut menunjukkan bahwa peran Komite Audit mempunyai pengaruh yang signifikan terhadap kualitas laporan keuangan di Bank Pembiayaan Rakyat Syariah. Dari penjelasan diatas, di dapatkan hipotesa sebagai berikut:

$\mathrm{H}_{1}$ : Diduga bahwa peran Komite Audit mempunyai pengaruh yang signifikan terhadap kualitas laporan keuangan di Bank Pembiayaan Rakyat Syariah Provinsi Jawa Timur.

Aspek kesesuaian dengan syariah merupakan aspek utama dan mendasar yang membedakan antara Bank Syariah dengan Bank Konvensional. Untuk itu, laporan keuangan yang berkualitas pada BPRS juga harus sesuai dengan prinsip akuntansi syariah yang berlaku peran DPS merupakan salah satu point yang sangat penting bagi terjadinya praktik Bank 
Syariah. Bila DPS benar-benar menjalankan wewenang dan kewajibannya (peran) bisa dipastikan bahwa laporan keuangan yang terjadi adalah laporan keuangan yang berkualitas dan sesuai dengan prinsip syariah. Hal ini sesuai dengan penelitian yang dilakukan oleh Rini (2014) tentang Pengaruh Penerapan Peran Komite Audit, Peran Dewan Pengawas Syariah, dan Efektivitas Pengendalian Intern Atas Pelaporan Keuangan Terhadap Kualitas Pelaporan Keuangan. Hasil penelitian tersebut menunjukkan bahwa peran Komite Audit, peran Dewan Pengawas Syariah dan Efektifitas Pengendalian Intern atas Pelaporan Keuangan berpengaruh secara simultan terhadap Kualitas Pelaporan Keuangan. Berdasarkan penjelasan tersebut, maka peneliti mendapatkan hipotesa sebagai berikut:

$\mathrm{H}_{2}$ : Diduga bahwa peran Dewan Pengawas Syariah mempunyai pengaruh yang signifikan terhadap kualitas laporan keuangan di Bank Pembiayaan Rakyat Syariah Provinsi Jawa Timur.

\section{METODE}

Penelitaian ini menggunakan pendekatan kuantitatif yang bersifat asosiatif. Sampel diambil dengan metode purposive sampling. Lokasi penelitian dilakukan di Bank Pembiayaan Rakyat Syariah (BPRS) yang berada di provinsi Jawa Timur, yang tidak mengalami kerugian sampai tahun 2017. Teknik pengumpulan data yang digunakan dalam penelitian ini adalah melalui kuisioner dan penelitian kepustakaan.

\section{HASIL DAN PEMBAHASAN}

Intergrtas dari sebuah laporan keuangan ialah laporan keuangan yang hanya mengemukakan keadaan perusahaan secara jujur dan transparan. Tugas seorang auditor menjadi cukup berat apabila auditor tersebut sedang menilai laporan keuangan yang tidak berintegritas. Hal ini dikarenakan dapat merugikan banyak pihak, terutama ketika kondisi laporan keuangan tersebut sedang overstate (Hardiningsih, 2010).

Hasil uji parsial Peranan Komite Audit terhadap Kualitas Laporan Keuangan dengan koefisien regresi sebesar 0,342, dan nilai signifikansi sebesar 0,000 artinya peranan Komite Audit berpengaruh positif dan signifikan terhadap Kualitas Laporan Keuangan. Secara umum, Komite Audit adalah sebuah komite yang dibentuk oleh Dewan Komisaris. Dalam hal ini Komite Audit membantu Dewan Komisaris untuk memenuhi tanggung jawab pengawasannya, yang meliputi penelaahan atas laporan tahunan auditan dan laporan keuangan, penelahaan terhadap proses pelaporan keuangan, sistem pengendalian internal, serta pengawasan atas proses audit. Dalam kapasitasnya, Komite Audit bertanggung jawab untuk membuka dan 
memelihara/menjaga komunikasi antara Komite Audit dengan Dewan Komisaris, Direksi, unit audit internal, akuntan independen dan manajer keuangan. Kualitas hasil audit dinilai dari runtutan tahapan mulai dari input, proses hingga output (Setiawan \& Fitriany, 2011).

Dewan Pengawas Syariah pada setiap lembaga keuangan syariah diramalkan akan dapat menciptakan fatwa yang beragam. Hal ini tentu menjadi kekhawatiran tersindi bagi lembaga keuangan islam karena akan membingunkan nasabah. Dalam rangka meminimalisir kekhawatiran tersebut, Majelis Ulama Indonesia sebagai organisasi islam di Indonesia mengusulkan untuk dibentuknya Dewan Syariah yang bersifat nasional. Dewan Syariah tersebut membawahi semua lembaga keuangan yang berasaskan syaria islam. Lemba independen disebut sebagai Dewan Pengawas Syariah (Prasetyoningrum, 2010).

Hasil uji parsial Peran Dewan Pengawas Syariah (DPS) terhadap Kualitas Laporan Keuangan menunjukkan hasil koefisien regresi sebesar 0,196, dan nilai signifikansi sebesar 0,000. Artinya DPS berpengaruh negatif terhadap Kualitas Laporan Keuangan. Ukuran DPS berpengaruh negatif terhadap kualitas laporan keuangan karena sering kali kasus-kasus yang menyimpang dari syariah Islam di bank syari'ah, lebih dahulu diketahui oleh Bank Indonesia daripada oleh DPS, sehingga DPS baru mengetahui adanya penyimpangan syari'ah setelah mendapat informasi dari Bank Indonesia. Selain itu, kurangnya pengawasan yang dilakukan oleh DPS di BPRS, DPS sering tidak memeriksa secara berkala transaksi-transaksi yang dilakukan BPRS dengan nasabah dapat menjadi pemicu tidak berpengaruhnya DPS terhadap kualitas laporan keuangan yang diterbitkan oleh BPRS.

Hasil Uji Simultan Dari hasil perhitungan didapatkan nilai signifikansi $F(0,000)<5 \%(0,05)$ artinya secara bersama-sama variabel bebas yang terdiri dari peranan DPS $\left(\mathrm{X}_{1}\right)$ dan Komite Audit $\left(\mathrm{X}_{2}\right)$ berpengaruh signifikan terhadap variabel Kualitas Laporan Keuangan. Hal ini menunjukkan bahwa tinggi rendahnya kualitas dan kredibilitas laporan keuangan juga dipengaruhi oleh peranan DPS dan Komite Audit. Dalam rangka mengeluarkan laporan keuangan yang kredibel, maka sebuah perusahaan harus meningkatkan kualitas komite audit dan juga DPS yang kredibel dibidannya.

\section{KESIMPULAN}

Hasil uji parsial Peranan Komite Audit terhadap Kualitas Laporan Keuangan memiliki pengaruh positif dan signifikan terhadap Kualitas Laporan Keuangan. Hal ini berarti jika Komite Audit menjalankan perannya semakin aktif dan semakin baik, maka laporan keuangan yang dihasilka oleh BPRS semakin baik dan berkualitas, sesuai dengan SAK yang berlaku. 
Hasil uji parsial Peran Dewan Pengawas Syariah (DPS) terhadap Kualitas Laporan Keuangan menunjukkan bahwa DPS tidak berperan secara langsung terhadap kualitas laporan keuangan yang dihasilkan oleh BPRS. DPS tidak berperan secara langsung terhadap kualitas laporan keuangan dikarenakan beberapa alasan, diantaranya yaitu karena kurangnya pengawasan yang dilakukan oleh DPS di BPRS. DPS sering tidak memeriksa secara berkala transaksi-transaksi yang dilakukan BPRS dengan nasabah.

Dari hasil penelitian menunjukkan bahwa variabel Komite Audit dan DPS secara simultan berpengaruh terhadap kualitas laporan keuangan. Hal ini ditunjukkan oleh hasil signifikansi 0,000, sehingga dapat disimpulkan secara bersama-sama peran komite audit dan DPS berpengaruh terhadap kualitas laporan keuangan pada BPRS Jawa Timur.

\section{DAFTAR PUSTAKA}

Adhi, D. K., \& Suhardjo, Y. (2013). Pengaruh Penerapan Standar Akuntansi Pemerintahan Dan Kualitas Aparatur Pemerintah Daerah Terhadap Kualitas Laporan Keuangan (Studi Kasus Pada Pemerintah Kota Tual). Jurnal Stie Semarang, 5 (3), 93-111.

Faozan, A. (2013). Implementasi Good Corporate Governance Dan Peran Dewan Pengawas Syariah Di Bank Syariah. La_Riba, 7 (1), 1-14. https://doi.org/10.20885/lariba.vol7.iss1.art1

Hardiningsih, P. (2010). Pengaruh Independensi, Corporate Governance, Dan Kualitas Audit Terhadap Integritas Laporan Keuangan. 2(1), 16.

Prasetyoningrum, A. K. (2010). Analisis Pengaruh Independensi dan Profesionalisme Dewan Pengawas Syariah terhadap Kinerja Bank Perkreditan Rakyat Syariah di Jawa Tengah. Jurnal Ilmiah Aset, 12 (1), 27-36.

Riduwan, R., Prasetyo, P. P., \& Adha, M. A. (2018). Penguatan Fungsi Dps Dalam Implementasi Prinsip Syariah Pada Btm Dan Bmt Milik Muhammadiyah Daerah Istimewa Yogyakarta. Jurnal Pemberdayaan: Publikasi Hasil Pengabdian Kepada Masyarakat, 2 (2), 291. https://doi.org/10.12928/jp.v2i2.385

Rini, R. (2014). Pengaruh Penerapan Peran Komite Audit, Peran Dewan Pengawas Syariah dan Efektivitas Pengendalian Intern atas Pelaporan Keuangan terhadap Kualitas Pelaporan Keuangan. Jurnal Akuntansi Dan Keuangan Islam, 2 (2), 143-155. https://doi.org/10.35836/jakis.v2i2.49

Setiawan, L., \& Fitriany, F. (2011). Pengaruh Workload Dan Spesialisasi Auditor Terhadap Kualitas Audit Dengan Kualitas Komite Audit Sebagai Variabel Pemoderasi. Jurnal Akuntansi dan Keuangan Indonesia, 8 (1), 36-53.

https://doi.org/10.21002/jaki.2011.03 
Sholikah, R. N., Astuti, D. S. P., \& Sunarko, M. R. (n.d.). Pengaruh Pengawasan Internal, Pemahaman Sistem Akuntansi Keuangan Dan Pengelolaan Keuangan Daerah Terhadap Kualitas Laporan Keuangan. 12, 8.

Suazhari, S. (2015). Pengaruh Pemahaman Manajer Tentang Standar Akuntansi Keuangan Syariah Dan Peran Dewan Pengawas Syariah Terhadap Kualitas Laporan Keuangan Bprs Di Aceh. Jurnal Perspektif Ekonomi Darussalam, 1 (1), 1-8. https://doi.org/10.24815/jped.v1i1.6516

Swingly, C., \& Sukartha, I. M. (2015). Pengaruh Karakter Eksekutif, Komite Audit, Ukuran Perusahaan, Leverage Dan Sales Growth Pada Tax Avoidance. E-Jurnal Akuntansi, 10 (1), 47-62.

Vivin, Y. A., \& Wahono, B. (n.d.). Analisis Perbandingan Kinerja Keuangan Bank Umum Syariah Dengan Bank Umum Konvensional Di Indonesia. 14.

Yosefrinaldi, Y. (2013). Pengaruh Kapasitas Sumber Daya Manusia dan Pemanfaatan Teknologi Informasi terhadap Kualitas Laporan Keuangan Pemerintah Daerah dengan Variabel Intervening Sistem Pengendalian Intern Pemerintah (Studi Empiris Pada Dinas Pengelolaan Keuangan dan Aset Daerah. Jurnal Akuntansi FE Universitas Negeri Padang, 1 (1), 1-12. 